DOI 10.18551/rjoas.2021-06.13

\title{
THE EFFECT OF SMES DEVELOPMENT ON GROSS REGIONAL DOMESTIC PRODUCTS IN WEST NUSA TENGGARA PROVINCE OF INDONESIA IN THE PERIOD OF 2010-2019
}

\author{
Rasidi Didi*, Hailuddin, Harsono Iwan \\ Graduate Program in Economics, University of Mataram, West Nusa Tenggara, Indonesia \\ *E-mail: didhot79@gmail.com
}

\begin{abstract}
The role of Small and Medium Enterprises (SMEs) in encouraging the acceleration of economic growth is very important. This sector must continue to be upgraded and active in order to advance and compete. The purpose of this study was to analyze the influence of the development of SME such as (SME manpower, SME Production Value, number of SME units, and SME investment) on the GRDP of the Province of NTB from 2010 to 2019. This study used quantitative methods. The research location was in the Province of West Nusa Tenggara. Data collection techniques used were literature studies and documentation. Simultaneously, the results of this study indicated that manpower, production value, number of units, and investment value of SME had positive effects on the growth of GRDP of the Province of NTB. Partially, the manpower, number of Small and Medium Enterprises variables showed insignificant effect, while the variables of production value and investment value showed significant results. The results of the study indicate that it is necessary to increase investment to increase the growth of gross regional domestic product and to pay more attention to the issue of labor quality.
\end{abstract}

\section{KEY WORDS}

Gross regional domestic product, small and medium enterprises, manpower, small production value, number of units, investment.

Small and Medium Enterprise (SME) has an important role in business development in every province of Indonesia. SME is also the forerunner of the growth of large businesses. Almost all big businesses start from SMEs. SMEs must continue to be upgraded and active in order to advance and compete with large companies. Otherwise, SME in Indonesia, which is the heart of the Indonesian economy, will not be able to progress and develop. Keep in mind that in the development of SMEs is that this step is not solely a step that must be taken by the government and is only the responsibility of the government. The SME itself, as the party being developed, can take steps together with the government. In addition to the government and SMEs, the role of the banking sector is also very important related to all matters regarding funding, especially in terms of providing loans or establishing banking policies.

The government has an obligation to participate in solving the basic managerial problems of SMEs that have not been resolved from year to year. Broadly speaking, these basic problems include: 1) SMEs still face difficulties in accessing the global market for the products they produce (Hery, et al, 2019); 2) there is still weak business development and strengthening (Jaswadi, 2016); and 3) there is limited access to financing from formal financial institutions, especially from banks (Zulkarnaeni, 2019). Previous research has revealed that the UMKM (Micro Small Medium Enterprises) sector faces more obstacles in accessing credit when compared to large companies (Beck and Demirguc-Kunt, 2006; Cull et al., 2006; Batra et al., 2003).

Empowerment and a good managerial system will greatly help from strengthening SMEs (Dewanti, 2010). The government as the front line is expected to have structured empowerment policies regarding related fundamental issues. The unresolved SMEs problems from previous years did not have much impact on the growth of SMEs nationally. Based on the expression of the Special Staff of the Minister of Economy and SMEs, that the 
number of SMEs in Indonesia in 2019 was 62.92 million units, or 99.92 percent of the total number of domestic businesses and always experienced positive growth (Deny, 2019). This indicates that the SMEs have a very good and well-established base strength. The role of SMEs in such complex problems is still able to contribute to National GDP in the last 5 years by 60.34 percent with a fairly high ability to absorb manpower, which was 97.22 percent (Tajuddien and Santoso, 2019).

The economic structure of a region is largely determined by immensity of the economic sectors role in producing goods and services (BPS: 2014). The economic structure formed from the added value generated by each sector informs the extent of regional dependence on the sector. During 2000-2019 the economic structure of NTB was still dominated by 4 sectors, namely: the service sector (tourism); trade, hotel and restaurant sector; agricultural sector; and the manufacturing sector (SMEs).

The GRDP of West Nusa Tenggara (NTB) Province at Constant Prices grew as follows: The years 2010 to 2014 experienced positive growth in the range of 1 to $2 \%$ from the previous years. Then in the following year there was a growth fluctuation, 2015 grew by $21.76 \%$ compared to 2014,2016 experienced a growth of $5.79 \%$ compared to 2015,2017 experienced a growth of $0.08 \%$ compared to 2016, but in 2018 GRDP of the Province of NTB decreased by $4.45 \%$ from 2017. The decline in GRDP of the Province of NTB in 2018 was due to a decrease in the performance of several subcategories of the impact of the earthquake that occurred in West Nusa Tenggara (Suntono, 2019).

The West Nusa Tenggara Province Enterprises Office stated that until the end of 2018, SMEs were recorded at 62,602 or $77.43 \%$ of the total number of business units. SMEs (Small and Medium Enterprises) absorbed as many as 141,048 workers or $64.37 \%$ of the total manpower in West Nusa Tenggara. The contribution of SMEs in the formation of GRDP was $23.45 \%$.

The problem raised in this study is: how is the effect of the development of Small and Medium Enterprises on the gross regional domestic product in the Province of NTB in 2010$2019 ?$

\section{METHODS OF RESEARCH}

This research is a quantitative descriptive research. This study examines the influence of Small and Medium Enterprises (SMEs) on the Gross Regional Domestic Product (GRDP) of West Nusa Tenggara Province. The type of data in this study is quantitative data. This study used multiple linear regression analysis techniques.

The variables used in this study are classified as follows: Gross Regional Domestic Product (GRDP), Manpower, SME Production Value, Number of SMEs, SMEs Investments:

- GRDP is the amount of gross value-added arising from all economic sectors in the area, with Rupiah as the measuring instrument;

- Manpower is the entire population of working age who has the potential to produce goods and services. This indicator is used to find out how many manpower or potential working age population can produce goods and services. In this case, the number of manpower is absorbed by the SME sector, with people as the measuring instrument;

- The Production value of SMEs are the total SMEs products traded by removing goods from inside to outside the territory of one country to another country by fulfilling applicable regulations, using Rupiah as the measuring instrument;

- The number of SME Units is the total number of business units that are included in the criteria for small and medium enterprises, with unit as the measuring instruments;

- In the SME sector for one or more assets owned are usually long terms with the hope of getting profits in the future, with Rupiah as the measuring instrument.

The hypothesis of this research was that there was a significant effect of the development of SME (SMEs manpower, SMEs Production Results, Number of SME units, and SMEs investment) on the Gross Regional Domestic Product of West Nusa Tenggara 
Province. Hypothesis testing was done through Partial Test, Simultaneous Test (F Test), and Coefficient of Determination Test $\mathrm{R}^{2}$

\section{RESULTS AND DISCUSSION}

The results of the study related to the influence of independent variables (Manpower, Production Value, Number of Units, and SMEs Investment Value) on the growth of GRDP of NTB Province as follows:

Table 1 - Simultaneous Test Result

ANOVA $^{\mathrm{a}}$
\begin{tabular}{|l|l|l|l|l|l|}
\hline Model & Sum of Squares & Df & Mean Square & F & Sig. \\
\hline 1 Regression & 1335396279505205600000.000 & 4 & 333849069876301400000.000 & 28.615 &, $001^{\mathrm{b}}$ \\
$\quad \begin{array}{l}\text { Residual } \\
\text { Total }\end{array}$ & 58334003598567670000.000 & 5 & 11666800719713534000.000 & & \\
\hline
\end{tabular}

a. Dependent Variable: GRDP of NTB Prov.

b. Predictors: (Constant), SME Investment Value, Number of Units of SME, SME Production Value, SME Manpower

This study shows that the $F$ value is 28.615 with a significant level of 0.001 while the $F$ table at the $95 \%$ confidence level $(0.05)$ was 2.73 . In both calculations $F$ value $>F$ table and the significance is $0.001<0.05$. This means the hypothesis simultaneously that the independent variable has an effect on the dependent variable. This means that the independent variables (Manpower, Production Value, Number of Units, and Investment Value of SMEs) has a positive effect on the growth of the GRDP of the Province of NTB.

The results of the partial test analysis shows that the two independent variables significantly affect the dependent variable and the other two independent variables do not meet the significance value:

1) Manpower. The results of the analysis show that the manpower variable has t-value of 0.683 and significance of 0.525 . In the $5 \%$ significance level, the SMEs manpower variable individually is not significant in affecting the growth of the GRDP of the Province of NTB.

2) Production Value of SMEs. The results of the analysis show that the SMEs production value variable has $t$-value of 0.298 and significance of 0.028 . At a significance level of $5 \%$, the SME production value variable individually is significant in affecting the growth of the GRDP of the Province of NTB.

3) The Number of SMEs. The results of the analysis show that the variable number of SME units has t-value of -1.018 and a significance of 0.355 . In the $5 \%$ significance level, the variable number of SME units individually is not significant in affecting the growth of GRDP of the Province of NTB

4) Investment Value. The results of the analysis show that the SMEs investment value variable has $t$-value of 2.788 and a significance of 0.039 . At the $5 \%$ significance level, the SMEs investment value variable individually is significant in affecting the growth of the GRDP of the Province of NTB

Table 2 - Coefficient of Determination $\left(R^{2}\right)$

Summary Model
\begin{tabular}{|l|l|l|l|l|}
\hline Model & R & R Square & Adjusted R Square & Std. Error of the Estimate \\
\hline 1 & $.979^{\mathrm{a}}$ & .958 & .925 & 3415669878.62023 \\
\hline
\end{tabular}

a. Predictors: (Constant), SME Investment Value, Number of Units of SME, SME Production Value, SME Manpower.

b. Dependent Variable: GRDP of NTB Prov.

The coefficient of determination $\left(R^{2}\right)$ from the multiple regression results shows how much the dependent variable (GRDP of NTB Province) is affected by the independent 
variables (SME manpower, SMEs production results, SME units, SMEs investment).

Based on the data above, the coefficient of determination $\left(R^{2}\right)$ is 0.958 or $(91.7 \%)$. This shows that $91.7 \%$ of the variables of GRDP growth are affected by manpower, production value, number of units, and the investment value of SME NTB Province, while $8.3 \%$ is affected by other variables that were not included in this research model.

\section{DISCUSSIONS OF RESULTS}

The analysis of the panel data in this study aimed to determine the effect of the development of Small and Medium Enterprises on the gross regional domestic product in the Province of NTB in 2010-2019. Based on the test results obtained, it shows that simultaneously, the significance of the variables tested indicates the influence of the development of Small and Medium Enterprises (variables of number of manpower, production value, number of units, and investment value of SME) on gross regional domestic product in NTB Province in 2010-2019.

A. Manpower. The results of the analysis show that the individual manpower variable has no effect on the gross regional domestic product in the Province of NTB. Referencing to previous research, this study stated that the absorption of SME manpower had a positive effect on the growth and formation of GRDP. Although statistically the movement of NTB's SMEs manpower absorption from 2010 experienced a positive increase, it experienced a considerable decline at the end of the calculation year, 2018 and 2019. Based on the table value, it was found that the regression coefficient value is 1.229 with a significance level of 0.0525 ( $\mathrm{sig}>0.05)$. So it could be interpreted that every $1 \%$ decrease in manpower absorption by NTB SMEs would have an effect on a $1.229 \%$ decrease in GRDP.

B. Production Value. The results of the analysis shows that individually the production value variable in this study has a significant effect on the GRDP of the Province of NTB from the data collected. Historically, even though the data from the production value showed a decrease in the last years of calculation - 2018 and 2019-, but still had an effect on the growth and formation of the GRDP of the Province of NTB. Based on the test results, it was found that the regression coefficient value of this variable reached 0.275 meaning if there is an increase of $1 \%$ of the production value, it will have an impact on the increase in regional GRDP by $0.275 \%$. The SMEs production value variable is one of two variables that has a significance value of $5 \%$ or 0.05 .

C. Number of Units of SMEs. Based on historical data, the number of SMEs of NTB units had quite a positive growth from the base year 2010 to 2017, only in the last year there had been a quite large correction in the decline in the number of SME of NTB. Meanwhile, the results of the test analysis shows that this variable individually does not have a positive effect on the GRDP variable. These data indicate that the regression coefficient value of the variable number of SME units is-1.957. This means that if there is a $1 \%$ decrease in the number of SME NTB, it will affect the decrease in GDP by $-1.957 \%$.

D. Investment Value of SMEs. The investment value of SMEs of NTB, although experiencing a fairly high fluctuating value, had a positive effect on GRDP. Based on the test results, it was found that the regression coefficient value for the variable SMEs investment value reaches 0.884 meaning that an increase of $1 \%$ of the SMEs investment value will have an impact on increasing GRDP by $0.884 \%$. This variable is also a variable that is one of the variables that has a positive effect on the dependent variable being tested.

\section{CONCLUSION AND SUGGESTIONS}

Based on the analysis, it can be concluded simultaneously the variables simultaneously, the significance of the variables tested state the influence of the 
development of Small and Medium Enterprises (variables of number of manpower, production value, number of units, and value of SMEs investment) on gross regional domestic products in the Province of NTB 2010-2019. The results of the test using the partial test method show that there are two independent variables that have positive effects on GRDP, which are the variables of the production value of SMEs and the investment value of SMEs, while the other two variables give negative significance to the GRDP. The variables are the SMEs manpower and the number of SMEs units.

Suggestions that can be given to the next study of this research in order to provide improvement and refinement of the results are: further research should pay attention to the time span of data collection, so that it can make observations of data movement more extensive and mature. In addition, the further research should pay attention to other variables that can affect GRDP.

\section{REFERENCES}

1. Ates, Aylin and Umit Bititci. 2007. Strategy management in small to medium-sized enterprises: Evidence from UK manufacturing SMEs. Strathclyde Institute for Operations Management, University of Strathclyde, Glasgow UK.

2. Adiningsih, S. (1999). Manajemen Produksi and Operasi. Jakarta: Fakultas Ekonomi Universitas Indonesia.

3. Bank Indonesia. 1997-2007. Statistik Ekonomi and Keuangan Indonesia. Jakarta: Bank Indonesia.

4. Badan Pusat Statistik. 2020. Statistik Indonesia. Jakarta: BPS.

5. Beck, T., A. Demirgüç-Kunt, L. Laeven, and R. Levine (2008). Finance, Firm Size, and Growth. Journal of Money, Banking and Credit, vol. 40, pp. 1379-1405.

6. Berger, A. N. and G. F. Udell (1995), Relationship Lending and Lines of Credit in Small Firm Finance, Journal of Business 68, 351-381.

7. Cahyono, B. 1983. Pengembangan Kesempatan Kerja. Yogyakarta: BPFE. Departemen Koperasi. 2008. PDB, Investasi, Tenaga Kerja, Nilai Ekspor IKM di Indonesia. Depkop. Jakarta.

8. Daryanto, Arief and Yundy Hafizrianda. 2010. Model-model Kuantitatif untuk Perencanaan Pembangunan Ekonomi Daerah: Konsep and Aplikasi. Bogor: IPB Press.

9. Deny Septian. 2018. Baru 9 Persen UMKM RI Masuk e-commerce. Diakses dari https://www.liputan6.com/bisnis/read/3582327/baru-9-persen-umkm-ri-yangmasuk-ecommerce. Tanggal 6 Februari 2019.

10. Budiyanto, Hery, et al. "Upaya Meningkatkan Produktivitas, Desain, and Pemasaran UKM Handicraft Studi Kasus: UKM Gift Box di Kota Malang." Seminar Nasional Sistem Informasi (SENASIF). Vol. 3. No. 1. 2019.

11. Gujarati, Damodar. 1999. Ekonometrika Dasar. Jakarta: Erlangga.

12. Ghozali, I. (2016). Aplikasi Analisis Multivariative dengan Program IBS SPSS 23. Semarang: BPFE Universitas Diponegoro.

13. Hanum, Wirda. 2010. Analisis Pengaruh Perkembangan Industri IKM terhadap Pertumbuhan Sektor Industri Sumatera Utara [Skripsi]. Fakultas Ekonomi. Universitas Sumatera Utara, Sumatera Utara.

14. Ikhsan, M. 2004. Mengembalikan Laju Pertumbuhan Ekonomi Dalam Jangka Menegah: Peran Usaha Kecil and Menengah. Jurnal Analisis Sosial 9 (2):1- 31 Jafar, Mohammad Hafsah.2004. "Upaya Pengembangan Usaha Kecil and Menengah (IKM)", Infokop Nomor 25 Tahun XX, 2004.

15. Kuncoro, M. 1996. Ekonomi Pembangunan: Teori, Masalah and Kebijakan. UMP KMP YPPM, Yogyakarta.

16. Riduwan, R., \& Adun, E. (2013). Cara Mudah Belajar SPSS Versi 17.0 and Aplikasi Statistik Penelitian. Bandung: Alfabeta.

17. Mankiw, N Gregory, 2007. Makro Ekonomi.Jakarta: Erlangga.

18. Nengah, I Dasi Astawa. 2007. Pemberdayaan IKM and Koperasi di Kabupaten Jembrana Provinsi Bali. Jurnal Ekonomi/Tahun XXI, No.01, Maret 2007:78- 95. 
19. Partomo, T. and A. Soejodono. 2004. Ekonomi Skala Kecil/Menengah and Koperasi. Ghalia, Jakarta.

20. Rafinaldy, Neddy. 2004. Prospek Pengembangan Ekspor IKM. Infokop Nomor 25 Tahun XX, 2004.

21. Rahardjo, M. D., and F. Ali. 1993. Faktor-faktor keuangan yang mempengaruhi Usaha Kecil and Menengah di Indonesia, dalam K. James and N. Akrasanee. Aspek-aspek Finansial Usaha Kecil and Menengah: Studi kasus Asean. Jakarta: LP3ES.

22. Rohana Sitanggang, Ignatia and Nachrowi Djalal. 2004. Pengaruh Struktur Ekonomi pada penyerapan tenaga kerja Sektoral: Analisis Model Demometrik di 30 Propinsi pada 9 sektor di Indonesia, Jurnal Ekonomi and Pembangunan Indonesia jurnal Vol No.01, Juli, 2004.

23. Samitasa, Aristeidis G and Dimitris F. 2005. Entrepreneurship, small and medium size business markets and European economic integration. Journal of Policy Modeling 27.

24. Soetrisno, Noer. 2004 Posisi and Peran Pembangunan IKM 2004-2009. Infokop Nomor 25 Tahun XX.

25. Sukirno, Sadono. 2007. Ekonomi Pembangunan (Proses, masalah, and kebijakan). Jakarta: Kencana Prenada.

26. Tambunan, Tulus. 2002. Usaha Kecil and Menengah di Indonesia: Beberapa Isu Penting. Jakarta: Salemba Empat.

27. Tejasari, Maharani. 2008. Peranan Sektor Usaha Kecil and Menengah dalam penyerapan Tenaga Kerja and Pertumbuhan Ekonomi [Skripsi]. Fakultas Ekonomi and Manajemen. Institut Pertanian Bogor, Bogor.

28. Thoha, Mahmud and Sukarna. 2006. Pemberdayaan IKM melalui Modal Ventura dalam Upaya Pengentasan Kemiskinan di Indonesia. Jurnal Ekonomi and Pembangunan (JEP), XIV (2) 2006.

29. Thoha, M. 2001. Dinamika Usaha Kecil and Rumah Tangga. LIPI. Jakarta.

30. Todaro, Michael P and Stephen C smith, 2006. Economic Development. Jakarta: Erlangga.

31. Widya A, Santikajaya. 2006. Analisis Dampak Perkembangan Usaha Kecil Menengah terhadap Pertumbuhan Ekonomi Regional Indonesia: Metode Data Panel Tahun 19982004. Fakultas Ekonomi. Universitas Indonesia.

32. Winarno, Wing Wahyu. 2007. Analisis Ekonometrika and Statistika dengan Eviews. UPP STIM YKPN. Yogyakarta.

33. Yudi Setianto, Anton. 2008. Panduan Lengkap Mengurus Perijinan and Dokumen. Jakarta: Sahabat.

34. Zuhal, 2010. Knowledge and Innovation Platform Kekuatan Daya Saing.Jakarta: Gramedia.

35. Reksohadiprodjo, Sukanto and Rorohad iwidjaya. 1992. Perencanaan and Pengawasan Produksi, Cetakan Ketiga, Yogyakarta, Badan Penerbit Fakultas Ekonorni UGM.

36. Riduwan, R., \& Adun, E. (2013). Cara Mudah Belajar SPSS Versi 17.0 and Aplikasi Statistik Penelitian. Bandung: Alfabeta.

37. Sugiyono. (2016). Metodologi Penelitian Kuantitatif, Kualitatif, and R\&D. Bandung: CV Alfabeta.

38. Suntono, A., Kadafi, M. A. (2019). IKM and Kekuatan Ekonomi. KINERJA, 16(1), 51-57.

39. Zuhri, A. A., \& Adiningsih, S. (1999). Pengaruh investasi PMA and PMDN serta kesempatan kerja terhadap pertumbuhan ekonomi daerah di Propinsi Daerah Tingkat I Jawa Tengah (Doctoral dissertation, [Yogyakarta]: Universitas Gadjah Mada).

40. Dewanti, I. S. (2010). Pemberdayaan Usaha Kecil and Mikro: Kendala and Alternatif Solusinya. Jurnal Administrasi Bisnis, 6(2), 1-10.

41. Hermawan, F. (2019). Pengaruh Perkembangan Industri Kecil and Menengah (Ikm) Terhadap Pertumbuhan Ekonomi Malang Raya (Doctoral dissertation, University of Muhammadiyah Malang).

42. Tuasikal, A. (2008). Pengaruh DAU, DAK, PAD, and PDRB terhadap belanja modal pemerintah daerah kabupaten/kota di Indonesia. Jurnal Telaah and Riset Akuntansi, 1(2), 124-142. 
43. Hapsari, pradnya paramita, dkk. 2014. "Pengaruh pertumbuhan Usaha Kecil and Menengah (UKM) terhadap pertumbuhan ekonomi daerah (studi di pemerintah kota batu)". Vol.17, No.2. (di unduh tanggal 20 januari 2016).

44. Subhan, Qazi Abdul, dkk. 2013. "inovation of SME and the impact of economic development in pakistan" jurnal bisnis internasional and ilmu sosial koferensi penelitian. Dubai, UAE, ISBN: 978-1-92269-18-4.

45. Coleman, D.C. 1966. "Industrial Growth and Industrial Revolutions" in E.M, Carus-Wilson. Essays in Economic History (volume 3). London: Edward Arnold Publishers Ltd.

46. Hutznet dalam Lim Suk-Jun, 1988. Politics of Industrialization: Formation of Divergent Industrial Orders In Korea And Taiwan. www.uchicago.edu.

47. Jaswadi, Jaswadi. "Analisis tingkat implementasi good corporate governance pada usaha kecil and menengah." Jurnal Siasat Bisnis 20.2 (2016): 161.

48. Zulkarnnaeni, Achmad Syahfrudin, and Novitasari Caesar Rizki. "Pengaruh Pendidikan Terakhir, Skala Usaha and Pelatihan Akuntansi Terhadap Penggunaan Informasi Akuntansi Pada Ukm (Studi Empiris Terhadap Ukm Di Desa Kedensari, Kecamatan Tanggulangin Kabupaten Sidoarjo)." JIAI (Jurnal IImiah Akuntansi Indonesia) 4.2 (2019). 